\title{
Dental Students' Evaluations of Practice Management Education and Interest in Business-Related Training: Exploring Attitudes Towards DDS/DMD-MBA Programs
}

\author{
Jae Young Han, Thomas Paron, Marc Huetter, Carol Anne Murdoch-Kinch, Marita R. Inglehart
}

Abstract: Being well prepared for a competitive business environment is crucial for future dentists. The aims of this study were to assess dental students' satisfaction with their practice management education, their current and future interest in businessrelated education and attending a DDS/DMD-MBA program, and the relationship between their demographic and other characteristics and their business education-related responses. The study, conducted in 2016 and 2017, surveyed students in all four years at the authors' home school and at other schools that did not have a DDS/DMD-MBA program. At the home school, 273 students responded (response rate 63\%); and 341 students from 11 of the 51 U.S. dental schools without a DDS/DMD-MBA program responded (respondents were from $21 \%$ of schools invited; the response rate of those students could not be calculated). The responding students disagreed that their school adequately prepared them for the business aspects of dentistry (mean=2.42 on a scale from $1=$ disagree strongly to $5=$ agree strongly). Large majorities agreed/strongly agreed that dentistry is a career that requires a certain amount of business acumen (95\%) and that they were very interested in learning about business (85\%). A total of $68 \%$ agreed/strongly agreed that their school should offer a dual DDS/DMD-MBA degree and $63 \%$ that they would consider enrolling in such a program. The more advanced the respondents were, the less satisfied they were with their practice management education $(r=-0.20 ; p<0.001)$. Female respondents were less interested in business-related education $(r=-0.20 ; p<0.001)$ and less likely to consider a DDS/DMD-MBA program than the males. Respondents planning to own a dental practice were more interested in additional current business education $(r=0.22 ; \mathrm{p}<0.001)$ and in future business education $(r=0.15 ; \mathrm{p}<0.001)$ than those without that plan. These results showed that a significant percentage of these dental students were interested in a DDS/ DMD-MBA program. The male students and students who planned to own a practice were more interested in business education than the female students and students who did not plan to own their own practice.

Jae Young Han, BS, is a dental student, School of Dentistry, University of Michigan; Thomas Paron, BS, is a dental student, School of Dentistry, University of Michigan; Marc Huetter, BS, is a dental student, School of Dentistry, University of Michigan; Carol Anne Murdoch-Kinch, DDS, PhD, is Dr. Walter H. Swartz Professor of Integrated Special Care Dentistry and Associate Dean for Academic Affairs, School of Dentistry, University of Michigan; and Marita R. Inglehart, Dr phil habil, is Professor, Department of Periodontics and Oral Medicine, School of Dentistry and Adjunct Professor, Department of Psychology, College of Literature, Science, and Arts, University of Michigan. Direct correspondence to Dr. Marita R. Inglehart, Department of Periodontics and Oral Medicine, University of Michigan School of Dentistry, 1011 N. University Street, Ann Arbor, MI 48109-1078; 734-763-8073; mri@umich.edu.

Keywords: dental education, dental students, practice management, dental practice, dentistry

Submitted for publication 2/1/18; accepted 6/9/18

doi: 10.21815/JDE.018.139

$\mathrm{D}$ uring the last two decades, changes in dental practice patterns have occurred in the U.S. ${ }^{1}$ While the percentage of solo practices decreased, the percentage of large group practices with 500 or more employees increased substantially. ${ }^{2}$ Most of these large group practices are dental service organizations (DSOs). ${ }^{3}$ A DSO is a conglomeration of dental practices that are managed by a single entity such as a private equity firm. While most states in the U.S. require that dentists own dental practices, ${ }^{4}$ nondentists can already own dental practices in 12 states, and this number is expected to increase rapidly. ${ }^{1}$ Even if licensed dentists in DSOs "own" the dental practice, these dentists are often employed by the corporation, ${ }^{1}$ allowing the employer to control operations. At the same time, as predicted by the business concept of economies of scale, ${ }^{5}$ the grand scale of DSO operations can decrease costs through means such as larger volume of services, large-scale implementation of electronic records and other technologies, and making favorable purchasing arrangements. ${ }^{6}$ DSOs are also able to recruit dental school graduates by offering good 
salaries and benefits packages and a work environment with new dental equipment, while relieving them of the challenges of running a business. ${ }^{6,7}$

In consideration of these changing dental practice patterns, it is now more important than ever that dental schools prepare graduates with solid practice management and leadership skills needed to succeed in this changing environment, including preparing them for leadership roles in these new practice models. ${ }^{8,9}$ Unfortunately, the results of the American Dental Education Association (ADEA) senior survey over the past decade showed that not all graduating seniors evaluated their practice management education as satisfactory. Only $57.9 \%$ of the graduates in 2009 agreed that "the curriculum devoted to practice administration was appropriate." 10 This percentage increased to $63 \%$ in the 2013 senior survey. ${ }^{11}$ In the survey of the graduating class of 2016 , only $38.8 \%$ reported feeling prepared and $12 \%$ well prepared for practice by their practice management education in dental school. ${ }^{12}$ In comparison to these percentages, over $90 \%$ of those seniors in 2016 reported that their education in dental disciplines such as operative/restorative dentistry (97.5\%) and fixed prosthodontics (91.2\%) prepared them for practice.

The less than optimal preparedness for practice management reported by graduating seniors can become increasingly more problematic as practice patterns continue to change. Having a solid understanding of business concepts such as marketing, loan procurement, and accounting might thus become more important than ever before. One central question therefore is how to better integrate practice management education into predoctoral dental curricula.

Suggestions for improving practice management education have included a proposal to require prerequisites in business education from dental school applicants ${ }^{13}$ and a call for exploring different didactic approaches to identify how to best educate students in this subject. ${ }^{14}$ These efforts are supported by the Commission on Dental Accreditation (CODA) standards, especially Standard 2-19 that states, "Graduates must be competent in applying the basic principles and philosophies of practice management, models of oral health care delivery, and how to function successfully as the leader of the oral health care team." ${ }^{15}$ However, a challenge for improving practice management education is the fact that predoctoral dental curricula are already overloaded with coursework. This situation raises the question of how business classes can be added successfully without compromising the curricular integrity of dental school programs. One possibility would be to offer an elective joint DDS/DMD-MBA program.

There is a long tradition of joint Doctor of Medicine (MD)-MBA programs. Back in 1987, Henry published an article in the Journal of the American Medical Association entitled "MD-MBA: A Dual Degree Whose Time Has Come."16 The number of MD-MBA programs grew from five in 1993 to more than 50 in $2010 .{ }^{17}$ Larson et al.'s analysis of the outcomes of these programs reported in 2003 that 27 students had graduated from joint programs in 1999, 42 graduated in 2000, and 61 in 2001. ${ }^{18}$ Those authors argued that joint MD-MBA programs were the vehicle for needed affiliations between management and medicine for medical school graduates who wanted to play prominent roles in the organization and delivery of medical care. In 2014, survey data from MD-MBA program graduates of the University of Pennsylvania showed that, over that program's 30year history, graduates had mostly positive attitudes about it and often attributed their career acceleration, professional flexibility, and credibility in multidisciplinary domains to their dual training. ${ }^{19}$

While the tradition of DDS/DMD-MBA programs has been shorter, 14 of the current 66 dental schools in the U.S. offer such a program, and an additional program began to enroll students for the 2018-19 academic year (Table 1). This number of DDS/DMD-MBA programs indicates a rising cooperation between dental and business schools, as well as increasing interest in administration/management education early in the careers of graduating dentists. Currently existing programs commonly aim to provide dental school graduates with skills necessary to successfully manage dental practices and personal portfolios, as well as to potentially expand their interests into new dental health care-related venues. ${ }^{20}$

One interesting and so far unexplored question is how dental students respond to such joint programs and whether there are subgroups of dental students who are interested in attending these programs. Based on findings from research in medicine, one factor could be gender. Krupat et al. analyzed the demographics of students who pursued a joint MD-MBA between 2008 and 2013 and found that they were overwhelmingly male $(72 \%){ }^{21}$ More recently, a 2016 report about application trends by the Graduate Management Admission Council noted that nearly two-thirds of applicants for all types of MBA programs were male. ${ }^{22}$ At the same time, Krupat et al. found that $64 \%$ of MD-MBA program graduates were interested in professional roles that would 


\section{Table 1. U.S. dental schools that offer a joint DDS/DMD-MBA program}

\begin{tabular}{|c|c|c|}
\hline Dental School & Associated Business School & Program Length \\
\hline $\begin{array}{l}\text { University of California, San Francisco School of Dentistry } \\
\text { (dentistry.ucsf.edu/programs/dds-mba) }\end{array}$ & University of San Francisco & 4 years \\
\hline $\begin{array}{l}\text { Howard University College of Dentistry (healthsciences.howard.edu/education/ } \\
\text { colleges/dentistry/programs/predoctoral-programs/DDS-MBA-program) }\end{array}$ & $\begin{array}{l}\text { Howard University School } \\
\text { of Business }\end{array}$ & $\mathrm{n} / \mathrm{a}$ \\
\hline $\begin{array}{l}\text { University of Louisville (UL) School of Dentistry (business.louisville.edu/ } \\
\text { faqs/dual-mbadoctor-of-medicine-in-dentistry-dmd/) }\end{array}$ & UL College of Business & $\mathrm{n} / \mathrm{a}$ \\
\hline $\begin{array}{l}\text { Harvard School of Dental Medicine (www.hbs.edu/mba/academic-experience/ } \\
\text { joint-degree-programs/Pages/harvard-school-of-dental-medicine.aspx) }\end{array}$ & Harvard Business School & 5 years \\
\hline $\begin{array}{l}\text { University of Nevada, Las Vegas (UNLV) School of Dental Medicine } \\
\text { (www.unlv.edu/degree/dual-mba-dmd) }\end{array}$ & UNLV Lee Business School & $\mathrm{n} / \mathrm{a}$ \\
\hline $\begin{array}{l}\text { Columbia University College of Dental Medicine (www.dental.columbia.edu/ } \\
\text { education/dds-program/dual-degree-programs/ddsmba) }\end{array}$ & Columbia Business School & 5 years \\
\hline $\begin{array}{l}\text { University at Buffalo (UB) School of Dental Medicine (mgt.buffalo.edu/ } \\
\text { degree-programs/master-of-business-mba/academic-options/ } \\
\text { dual-collaborative/dds-dental.html) }\end{array}$ & UB School of Management & 5 years \\
\hline $\begin{array}{l}\text { University of Pennsylvania (UPenn) School of Dental Medicine } \\
\text { (www.dental.upenn.edu/academic_programs_admissions/dmd_ } \\
\text { program/dual-degree_options) }\end{array}$ & UPenn Wharton School & 5 years \\
\hline Temple University Kornberg School of Dentistry & Temple Fox School of Business & $\mathrm{n} / \mathrm{a}$ \\
\hline $\begin{array}{l}\text { Roseman University of Health Sciences College of Dental Medicine } \\
\text { (dental.roseman.edu/orthodontic-residency-aeodomba/) }\end{array}$ & $\begin{array}{l}\text { Roseman University of } \\
\text { Health Sciences }\end{array}$ & $\mathrm{n} / \mathrm{a}$ \\
\hline $\begin{array}{l}\text { West Virginia University (WVU) School of Dentistry (dentistry.hsc.wvu.edu/ } \\
\text { education/programs/dual-degree-programs/) }\end{array}$ & $\begin{array}{l}\text { WVU College of Business } \\
\text { and Economics }\end{array}$ & $\mathrm{n} / \mathrm{a}$ \\
\hline $\begin{array}{l}\text { New York University (NYU) College of Dentistry (www.stern.nyu.edu/ } \\
\text { programs-admissions/mba-programs/dual-degrees/dds-mba) }\end{array}$ & NYU Stern School of Business & 5 years \\
\hline $\begin{array}{l}\text { Dental College of Georgia at Augusta University (AU) (catalog.augusta.edu/ } \\
\text { preview_program.php?catoid=30\&poid }=4725 \& \text { returnto }=3565 \text { ) }\end{array}$ & $\begin{array}{l}\text { AU James M. Hull College } \\
\text { of Business }\end{array}$ & 4 years \\
\hline University of Alabama at Birmingham School of Dentistry & Collat School of Business & 4 years \\
\hline \multicolumn{3}{|l|}{ Newly introduced programs } \\
\hline $\begin{array}{l}\text { University of Michigan (UM) School of Dentistry (dent.umich.edu/news/2017/ } \\
\text { 10/10/dds-meets-mba-new-degree-program-announced\#sthash.nE9rfg2q.dpbs) }\end{array}$ & UM Ross School of Business & 5 years \\
\hline Rutgers School of Dental Medicine & Rutgers Business School & 4 years \\
\hline
\end{tabular}

allow them to have both clinical and administrative responsibility. ${ }^{21}$ These findings raise the question of whether these two factors-gender and type of career goals - also play a role in which dental students may be interested in a joint DDS/DMD-MBA program. The aims of this study were to assess dental students' satisfaction with their practice management education, their current and future interest in business-related education and attending a DDS/ DMD-MBA program, and the relationship between their demographic and other characteristics and their business education-related responses.

\section{Methods}

This study was determined to be exempt from oversight by the Health Sciences and Behavioral Sciences Institutional Review Board (IRB) at the
University of Michigan. The research at the home school (University of Michigan) was determined to be exempt from IRB oversight on September 16, 2016 (HUM00119764) and the study at the national level on January 18, 2017 (Amendment 000667792 for HUM00119764).

An a priori power analysis was conducted with the program package $G^{*}$ Power 3.1.2 (www.psycho. uni-duesseldorf.de/abteilungen/aap/gpower3) to determine the sample size needed to have the power to test the questions of interest. One specific focus of this study was to explore whether there were significant relationships between the students' characteristics and their DDS/DMD-MBA-related answers. The power analysis therefore was used to determine the sample size needed to detect significant correlations when a t-test would be used to test whether these correlations were significant, assuming alpha $=0.05$, power $=0.80$, and a small effect size of rho $=0.10$, 
when using one-sided tests to test these relationships. The power analysis determined that a total sample size of 614 students would be required.

A first draft of the survey was developed based on the objectives of interest. This survey was pilot tested with three dental students. Revisions were made, and the final version of the survey was uploaded to Qualtrics. At the home school, all predoctoral dental students in fall 2016 received a recruitment email from the research team, informing them about this research and asking them to respond to an anonymous web-based survey. In addition, announcements about this research and the upcoming email were made in classes to increase the likelihood of student responses.

The academic dean of the home school (coauthor CAMK) sent an email in 2017 to the academic deans of the other 51 U.S. dental schools without a joint DDS/DMD-MBA program, informing them about the study and asking them to forward a recruitment email to their students. This recruitment email for the students explained the purpose of the study and provided a web-link for the students to the anonymous survey. No follow-up emails were sent.

The survey instrument consisted of five parts. Part 1 asked questions about the respondents' characteristics such as their gender, age, year in program, work-related experiences, and whether they had considered obtaining an MBA. Part 2 consisted of two Likert-scale questions concerning students' satisfaction with the business-related education at their dental school and six questions concerning their considerations related to their own business-related education. Part 3 consisted of 13 Likert-scale questions that explored the students' interest in future business-related education and their motivation to obtain an MBA. In addition, three items were used to asses a lack of motivation in a business degree.

The collected data were downloaded from the website as an SPSS file (Version 22; IBM Corp., Armonk, NY, USA). Descriptive statistics such as frequencies, percentages, means, and standard deviations were computed to provide an overview of the responses. Inferential statistics were used to determine whether the responses of students at the home school and students at the other schools differed significantly. In addition, inferential statistics were used to test whether the correlations between certain characteristics and business-related responses were significant. To create indices based on responses to the Likert-scale items, two factor analyses were conducted, one with the eight items concerning students' current business-related education and one with the
16 items concerning future interests. These factor analyses used a Principle Component Analysis as the extraction method and a Varimax with Kaiser Normalization Rotation Method. The items loading on the two factors identified in the first analysis and the items loading on the two factors identified in the second analysis were used to create four indices. The indices were computed by averaging the responses to the items that loaded on each of the four factors, respectively. Cronbach's alpha coefficients were used to determine the inter-item consistency of these four scales. The indices "Satisfaction with the current business-related education," "Current businessrelated interest," and "Interest in future business education" had satisfactory to excellent inter-item consistency. ${ }^{23,24}$ The "Lack of interest/motivation in business-related education" index was just under the critical Cronbach's alpha level of 0.70 . Given the high number of correlations computed, Bonferroni corrections were used to avoid false positive results, and the significance level was therefore set at $\mathrm{p}<0.001$.

\section{Results}

A total of 273 students at the home school and 341 students at dental schools without a joint DDS/ DMD-MBA program responded to the survey, for a total of 614, the same number found to be needed as a sample size in the power analysis. At the home school, a total of 273 students responded, for a response rate of $63 \%$. A total of 341 students from 11 of the 51 U.S. dental schools without a joint DDS/ DMD-MBA program responded to the survey. There were respondents from $21 \%$ of the schools invited; the response rate of students at those schools could not be calculated.

Table 2 provides an overview of the characteristics of respondents in the home school vs. those from other U.S. dental schools. Students from all four years of the predoctoral program responded to the survey. Respondents' ages ranged from 21 to 40 years at the home school and from 20 to 47 years at the other schools. Among the respondents, $80 \%$ at the home school and 78\% from other schools would like to own their own dental practices in the future. In addition, $70 \%$ of respondents in the home school and $71 \%$ in other schools had work experience before starting dental school, and $18 \%$ in the home school and $23 \%$ in other schools had prior business-related education. Furthermore, $23 \%$ of respondents from the home school and $28 \%$ from other schools had considered going to business school prior to entering 
Table 2. Responding students' characteristics by home school vs. other schools

\begin{tabular}{|c|c|c|c|}
\hline Characteristic & $\begin{array}{c}\text { Home School } \\
\quad N=273\end{array}$ & $\begin{array}{l}\text { Other Schools } \\
\qquad N=341\end{array}$ & $\begin{array}{c}\text { Total } \\
\mathrm{N}=614\end{array}$ \\
\hline \multicolumn{4}{|l|}{ Year in program } \\
\hline $1 \mathrm{st}$ & $39 \%$ & $32 \%$ & $35 \%$ \\
\hline $2 \mathrm{nd}$ & $36 \%$ & $34 \%$ & $35 \%$ \\
\hline $3 \mathrm{rd}$ & $15 \%$ & $18 \%$ & $17 \%$ \\
\hline 4th & $11 \%$ & $16 \%$ & $14 \%$ \\
\hline \multicolumn{4}{|l|}{ Gender } \\
\hline Male & $54 \%$ & $46 \%$ & $50 \%$ \\
\hline Female & $46 \%$ & $54 \%$ & $50 \%$ \\
\hline Age: Mean & 24.64 & 26.04 & 25.46 \\
\hline SD/Range & $3.046 / 21-40$ & $3.746 / 20-47$ & $3.537 / 20-47$ \\
\hline \multicolumn{4}{|l|}{ After graduating, I will } \\
\hline Work right away & $63 \%$ & $61 \%$ & $62 \%$ \\
\hline Continue education & $35 \%$ & $39 \%$ & $38 \%$ \\
\hline Unsure & $2 \%$ & 0 & $1 \%$ \\
\hline \multicolumn{4}{|l|}{ Type of education to continue in } \\
\hline GPR & $8 \%$ & $10 \%$ & $9 \%$ \\
\hline AEGD & $5 \%$ & $9 \%$ & $7 \%$ \\
\hline Specialty & $20 \%$ & $21 \%$ & $22 \%$ \\
\hline MBA & $1 \%$ & $1 \%$ & $1 \%$ \\
\hline \multicolumn{4}{|l|}{ In the long run, I would like to } \\
\hline Own practice & $80 \%$ & $78 \%$ & $79 \%$ \\
\hline Be employee/associate & $5 \%$ & $12 \%$ & $11 \%$ \\
\hline Work for dental service organization & $7 \%$ & $1 \%$ & $6 \%$ \\
\hline Work in community clinic & $5 \%$ & $4 \%$ & $5 \%$ \\
\hline Before dental school, did you have work experience? Yes & $70 \%$ & $71 \%$ & $71 \%$ \\
\hline Did you have business-related education? Yes & $18 \%$ & $23 \%$ & $21 \%$ \\
\hline Have you considered going to business school? Yes & $23 \%$ & $28 \%$ & $26 \%$ \\
\hline
\end{tabular}

Note: The "Home School" was that of the authors (University of Michigan); "Other Schools" were 11 of the 51 U.S. dental schools without a DDS/DMD-MBA program.

dental school programs. The fact that the responses of students at the home school did not differ significantly from those of students at the other dental schools justified analyzing the combined data.

Responses concerning the students' current education about practice management and businessrelated aspects are shown in Table 3. The first two questions of interest asked how satisfied students were with the business-related training their dental school offered and the level of business-related education they received. Overall, only $12 \%$ of the respondents agreed/agreed strongly that they were satisfied with the current training, and only $11 \%$ agreed/agreed strongly that their dental school adequately prepared them for the business aspects of dentistry.

A second set of six questions asked for students' perspectives concerning their current businessrelated education in their dental school. Large majorities of respondents agreed/strongly agreed with the statements that they were very interested in learning about functional areas of business $(85 \%)$, that it is important that dentists learn about these business elements $(94 \%)$, and that dentistry is a career that requires a certain amount of business acumen (95\%). An absolute majority (90\%) also agreed/strongly agreed that it would be helpful to have experts from outside dentistry supplement the business education at the dental school.

The third research question focused on students' degree of interest or lack of interest in future business-related education. Three items loaded on a factor described as a lack of interest/motivation. Most respondents $(66 \%)$ disagreed/disagreed strongly that they had no interest in a business degree or dual degree (Table 3), while $40 \%$ disagreed/disagreed strongly that there is a difference between business acumen and entrepreneurship and that therefore undergoing a business program would be unnecessary for their scope of practice as a dentist. However, $41 \%$ agreed/strongly agreed that they can be equally successful in their practice without a business degree. 
Table 3. Students' responses about business-related aspects of their dental education, by percentage of total respondents $(\mathrm{N}=614)$

\begin{tabular}{|c|c|c|c|c|c|c|}
\hline Item & 1 & 2 & 3 & 4 & 5 & $\begin{array}{l}\text { Mean } \\
\text { SD }\end{array}$ \\
\hline \multicolumn{7}{|l|}{ Positive evaluation } \\
\hline I am satisfied with the business-related training my dental school offers. & $18 \%$ & $30 \%$ & $41 \%$ & $8 \%$ & $4 \%$ & $\begin{array}{c}2.49 \\
0.995\end{array}$ \\
\hline My dental school adequately prepares me for the business aspects of dentistry. & $20 \%$ & $33 \%$ & $37 \%$ & $8 \%$ & $3 \%$ & $\begin{array}{c}2.42 \\
0.995\end{array}$ \\
\hline Index: satisfaction with current business-related education (Cronbach's alpha=0.879) & \multicolumn{2}{|c|}{ Mean: 2.45} & \multicolumn{2}{|c|}{ SD: 0.941} & \multicolumn{2}{|c|}{ Range: $1-5$} \\
\hline \multicolumn{7}{|l|}{ Considerations of business-related education in dental school } \\
\hline $\begin{array}{l}\text { I am very interested in learning about functional areas of business, } \\
\text { such as accounting, marketing, real estate, investment, strategy, law, } \\
\text { and operations management. }\end{array}$ & $2 \%$ & $4 \%$ & $10 \%$ & $31 \%$ & $54 \%$ & $\begin{array}{c}4.31 \\
0.913\end{array}$ \\
\hline It is important that dentists learn about these business elements. & $1 \%$ & $1 \%$ & $4 \%$ & $25 \%$ & $69 \%$ & $\begin{array}{c}4.60 \\
0.698\end{array}$ \\
\hline $\begin{array}{l}\text { It would be helpful to have experts from outside of dentistry supplen } \\
\text { business education at the dental school. }\end{array}$ & $1 \%$ & $2 \%$ & $7 \%$ & $43 \%$ & $47 \%$ & $\begin{array}{c}4.32 \\
0.796\end{array}$ \\
\hline Dentistry is a career that requires a certain amount of business acumen. & $1 \%$ & $1 \%$ & $3 \%$ & $34 \%$ & $61 \%$ & $\begin{array}{c}4.54 \\
0.685\end{array}$ \\
\hline I have interests in business beyond operating a dental practice. & $7 \%$ & $19 \%$ & $20 \%$ & $24 \%$ & $30 \%$ & $\begin{array}{l}3.51 \\
1.291\end{array}$ \\
\hline $\begin{array}{l}\text { I feel that certain aspects of business or practice management are missing in } \\
\text { our dental curriculum that could be addressed by a business program. }\end{array}$ & $3 \%$ & $4 \%$ & $24 \%$ & $43 \%$ & $27 \%$ & $\begin{array}{l}3.87 \\
0.941\end{array}$ \\
\hline Index: current business-related interest (Cronbach's alpha=0.773) & Mean: & : 4.19 & SD: ( & .621 & Range & e: $1-5$ \\
\hline
\end{tabular}

Note: Response options were $1=$ strongly disagree, $2=$ disagree, $3=$ neutral, $4=$ agree, and $5=$ strongly agree. Percentages may not total $100 \%$ due to rounding.

Thirteen items assessed students' degree of interest in future business-related education (Table 4). Responses to statements concerning interest in a joint DDS/DMD-MBA program were quite positive. The majority agreed/strongly agreed that their school should offer a dual degree (68\%), that they would strongly consider enrolling (63\%), and that offering a dual degree program would have positively affected their decision to apply to a dental school (53\%). In fact, $73 \%$ of the respondents agreed/strongly agreed that, if time were not an issue and finances were not an issue, they would apply to a joint program. However, only $27 \%$ agreed/strongly agreed that they would rather enroll in a business program as a dentist and not as a dental student.

A final objective was to explore whether there were significant relationships between three types of characteristics-respondents' demographics (age, gender), year in program, and business-related background such as work experiences and businessrelated experiences - and the four business-related indices concerning their satisfaction with their current business-related education and their current interests and considerations for the future. The more advanced the students were in the program, the less satisfied they were with their current business-related education $(\mathrm{r}=-0.20 ; \mathrm{p}<0.001)$ (Table 5). Female respondents were less likely than male respondents to want to own their own practice in the long run $(\mathrm{r}=-0.24 ; \mathrm{p}<0.001)$, were less likely to consider going to business school $(\mathrm{r}=-0.14 ; \mathrm{p}<0.001)$ or earning an MBA ( $\mathrm{r}=-0.17 ; \mathrm{p}<0.001)$, and had fewer businessrelated interests $(r=-0.20 ; \mathrm{p}<0.001)$. The more the respondents agreed that they wanted to own their own practice in the long run, the higher their current business education-related interests were $(\mathrm{r}=0.22$; $\mathrm{p}<0.001)$ and the more interested they were in future business education $(\mathrm{r}=0.15 ; \mathrm{p}<0.001)$. The more the respondents had considered going to business school before starting dental school, the more they considered an MBA in the future $(r=0.18 ; \mathrm{p}<9.001)$, the more current business-related interests they had $(r=0.29 ; p<0.001)$, and the more they were interested in future business education $(\mathrm{r}=0.33 ; \mathrm{p}<0.001)$.

\section{Discussion}

Before discussing the findings of this study, it is important to note that the sample size of 614 student participants was sufficient to test the questions of interest based on an a priori power analysis. In addition, including students from 12 dental schools 
Table 4. Students' interest in future business-related education, by percentage of total respondents $(\mathrm{N}=614)$

\begin{tabular}{|c|c|c|c|c|c|c|}
\hline Item & 1 & 2 & 3 & 4 & 5 & $\begin{array}{l}\text { Mean } \\
\text { SD }\end{array}$ \\
\hline \multicolumn{7}{|l|}{ Lack of interest/motivation } \\
\hline I believe that I can be equally successful in my practice without a business degree. & $4 \%$ & $18 \%$ & $36 \%$ & $31 \%$ & $10 \%$ & $\begin{array}{l}3.26 \\
1.001\end{array}$ \\
\hline $\begin{array}{l}\text { There is a difference between business acumen and entrepreneurship, so } \\
\text { undergoing a business program is unnecessary for my scope of practice as a dentist. }\end{array}$ & $10 \%$ & $30 \%$ & $42 \%$ & $14 \%$ & $4 \%$ & $\begin{array}{c}2.73 \\
0.970\end{array}$ \\
\hline I have no interest in a business degree or dual-degree program. & $26 \%$ & $40 \%$ & $20 \%$ & $9 \%$ & $5 \%$ & $\begin{array}{l}2.27 \\
1.088\end{array}$ \\
\hline Lack of motivation index (Cronbach's alpha $=0.674)$ & Mean: & 2.75 & SD: & 0.793 & Rang & e: $1-5$ \\
\hline \multicolumn{7}{|l|}{ Interest in future business-related education } \\
\hline Having an MBA would make me a better dentist. & $5 \%$ & $18 \%$ & $27 \%$ & $33 \%$ & $16 \%$ & $\begin{array}{l}3.37 \\
1.111\end{array}$ \\
\hline My school should offer a DDS/DMD-business degree. & $3 \%$ & $7 \%$ & $22 \%$ & $38 \%$ & $30 \%$ & $\begin{array}{c}3.86 \\
1.015\end{array}$ \\
\hline I would strongly consider enrolling in a dual DDS/DMD-business program. & $6 \%$ & $14 \%$ & $17 \%$ & $33 \%$ & $30 \%$ & $\begin{array}{l}3.66 \\
1.209\end{array}$ \\
\hline I would be interested in dual-enrolling now. & $13 \%$ & $20 \%$ & $18 \%$ & $27 \%$ & $21 \%$ & $\begin{array}{l}3.24 \\
1.334\end{array}$ \\
\hline I would rather enroll in a business program as a dentist, not as a dental student. & $9 \%$ & $29 \%$ & $35 \%$ & $20 \%$ & $7 \%$ & $\begin{array}{l}2.87 \\
1.048\end{array}$ \\
\hline $\begin{array}{l}\text { Offering dual enrollment for DDS/DMD and a business program would have } \\
\text { positively affected my decision to apply to my school. }\end{array}$ & $9 \%$ & $15 \%$ & $25 \%$ & $29 \%$ & $22 \%$ & $\begin{array}{l}3.38 \\
1.241\end{array}$ \\
\hline $\begin{array}{l}\text { I would be interested in obtaining a business degree because of the value } \\
\text { of its credentials. }\end{array}$ & $7 \%$ & $17 \%$ & $23 \%$ & $38 \%$ & $15 \%$ & $\begin{array}{l}3.37 \\
1.140\end{array}$ \\
\hline $\begin{array}{l}\text { I would be interested in obtaining a business degree because it would } \\
\text { offer me education, experience, and network opportunities that I would } \\
\text { not be able to obtain otherwise. }\end{array}$ & $4 \%$ & $9 \%$ & $16 \%$ & $45 \%$ & $27 \%$ & $\begin{array}{l}3.81 \\
1.058\end{array}$ \\
\hline I would dedicate time to take the GMAT or GRE. & $18 \%$ & $22 \%$ & $26 \%$ & $25 \%$ & $10 \%$ & $\begin{array}{c}2.88 \\
1.254\end{array}$ \\
\hline $\begin{array}{l}\text { I am willing to allocate the necessary amount of time needed to obtain } \\
\text { a business degree. }\end{array}$ & $10 \%$ & $19 \%$ & $27 \%$ & $31 \%$ & $12 \%$ & $\begin{array}{l}3.16 \\
1.177\end{array}$ \\
\hline If time were not an issue, I would choose to apply. & $5 \%$ & $8 \%$ & $15 \%$ & $36 \%$ & $37 \%$ & $\begin{array}{c}3.93 \\
1.119\end{array}$ \\
\hline I am willing to allocate necessary expenses to obtain a business degree. & $12 \%$ & $24 \%$ & $30 \%$ & $23 \%$ & $12 \%$ & $\begin{array}{c}2.99 \\
1.186\end{array}$ \\
\hline If finances were not an issue, I would choose to apply. & $5 \%$ & $8 \%$ & $14 \%$ & $35 \%$ & $38 \%$ & $\begin{array}{c}3.91 \\
1.153\end{array}$ \\
\hline Interest in future business education index (Cronbach's alpha=0.941) & Mean: & 3.46 & SD: & 0.910 & Rang & e: $1-5$ \\
\hline
\end{tabular}

Note: Response options were $1=$ strongly disagree, $2=$ disagree, $3=$ neutral, $4=$ agree, and $5=$ strongly agree. Percentages may not total $100 \%$ due to rounding.

in the sample and having a wide range of students from all four years provided a basis to explore the questions of interest. However, it is also important to note that only students from dental schools that did not offer a joint DDS/DMD-MBA program were invited to participate. Future research could explore how students at dental schools with a joint program differ in their business-related interests from students at dental schools that do not offer such a program.

We anticipated that the level of these dental students' satisfaction with their practice management preparation would to be low due to findings from ADEA's national surveys of dental school seniors. Those surveys found that about half of the graduating seniors in $2014(47.8 \%),{ }^{25} 2015(47.1 \%),{ }^{26}$ and
$2016(48.7 \%)^{12}$ felt underprepared/somewhat underprepared for practice management. This percentage might even be higher if graduates were surveyed sometime after graduation when they had some practice experience. A 2010 survey of one school's alumni from the graduating years 1997 to 2007 found that $85 \%$ of respondents were uncomfortable with their practice management education and reported that they had felt unprepared at the time of graduation. ${ }^{27}$ The fact that only $12 \%$ of our respondents agreed/strongly agreed that they were satisfied with the business-related training their dental school offered and that only $11 \%$ agreed/strongly agreed that their dental school adequately prepared them for the business aspects of dentistry should raise concern. 
Table 5. Correlations between responding students' professional characteristics and business-related educational responses

\begin{tabular}{|c|c|c|c|c|c|c|c|c|}
\hline Characteristic & $\begin{array}{c}\text { Program } \\
\text { Year }\end{array}$ & Age & Gender & $\begin{array}{c}\text { A } \\
\text { Own } \\
\text { Practice }\end{array}$ & $\begin{array}{c}\text { B } \\
\text { Work } \\
\text { Experience }\end{array}$ & $\begin{array}{c}\text { C } \\
\text { Business } \\
\text { Experience }\end{array}$ & $\begin{array}{c}\text { D } \\
\text { MBA } \\
\text { Considered }\end{array}$ & $\begin{array}{c}\mathrm{E} \\
\text { Future MBA } \\
\text { Considered }\end{array}$ \\
\hline $\begin{array}{l}\text { A. In the long run, I would } \\
\text { like to own a practice. }\end{array}$ & -0.02 & -0.04 & $-0.24^{* * *}$ & 1 & -0.02 & $0.09 *$ & 0.04 & 0.03 \\
\hline $\begin{array}{l}\text { B. I had work experience } \\
\text { before dental school. }\end{array}$ & -0.06 & $0.22^{* * *}$ & -0.05 & -0.02 & 1 & $0.10^{*}$ & $0.10^{*}$ & -0.01 \\
\hline $\begin{array}{l}\text { C. I had business-related work } \\
\text { experience. }\end{array}$ & 0.05 & $0.10^{*}$ & $-0.11 * *$ & $0.09 *$ & $0.10^{*}$ & 1 & $0.31 * * *$ & 0.08 \\
\hline $\begin{array}{l}\text { D. I considered going to business } \\
\text { school in past. }\end{array}$ & -0.05 & $0.11^{*}$ & $-0.14^{* * *}$ & 0.04 & $0.10^{*}$ & $0.31^{*}$ & 1 & $0.18^{* * *}$ \\
\hline E. I will consider an MBA in the future. & -0.05 & -0.03 & $-0.17^{* * *}$ & 0.03 & -0.01 & 0.08 & $0.18^{* * *}$ & 1 \\
\hline $\begin{array}{l}\text { Index: satisfaction with current } \\
\text { business-related education }\end{array}$ & $-0.20^{* * *}$ & * -0.01 & 0.01 & 0.02 & 0.05 & $<0.001$ & -0.04 & $-0.15^{* *}$ \\
\hline Index: current business-related interest & 0.01 & $0.09 *$ & $-0.20^{* * *}$ & $0.22^{* * *}$ & 0.05 & $0.09 *$ & $0.29 * * *$ & $0.20^{* * *}$ \\
\hline $\begin{array}{l}\text { Index: lack of business-related } \\
\text { education motivation }\end{array}$ & 0.03 & -0.01 & -0.00 & -0.05 & 0.02 & $-0.14^{* * *}$ & $-0.17^{* * *}$ & $-0.17^{* * *}$ \\
\hline $\begin{array}{l}\text { Index: interest in future business } \\
\text { education }\end{array}$ & -0.06 & -0.05 & $-0.10^{*}$ & $0.15^{* * *}$ & -0.01 & 0.07 & $0.33^{* * *}$ & $0.33^{* * *}$ \\
\hline${ }^{*} \mathrm{p}<0.05 ;{ }^{* *} \mathrm{p}<0.01 ;{ }^{* * *} \mathrm{p}<0.001$ & & & & & & & & \\
\hline
\end{tabular}

Given this relatively high level of dissatisfaction with these students' current business-related education, it is not surprising that a great majority expressed strong interest in introducing more business education into their curricula and expressed positive business education-related attitudes. The finding that $94 \%$ of respondents felt that it was important for dentists to learn about business elements and that $85 \%$ were interested in learning about functional areas of business, such as accounting, marketing, real estate, investment, strategy, law, and operations management, was noteworthy. These responses might be informed by an understanding that changes are occurring in the way dental practices are organized in the U.S. ${ }^{1,28}$ Looking at the future of dentistry and what dentists need to know to be prepared for the future, Weintraub summarized in 2017 that disruptive changes will continue to occur in dental science and technology, treatment modalities, and services provided by generalists vs. specialists, reimbursement, regulation, and legislation. ${ }^{29}$ She concluded that knowledge and skills needed by faculty will also change and that dental educators will need to update their own skills and educational standards and adapt their curricula and methods to prepare learners for what oral health professionals will need to know in the future.
Concerning the development of business expertise, a look at developments in medicine can be informative. As the delivery of medical care rapidly changed over the past two decades, medical administration also grew, and medical education responded to this need to train health executives by creating dual-degree programs in medicine and business administration (MD-MBA). ${ }^{21}$ The number of MD-MBA programs grew from six in 1993 to 33 in 2001, so that currently nearly $40 \%$ of U.S. medical schools offer an MD-MBA program. While these programs range in their approaches concerning the level of integration of the two degrees, they focus on complementing medical education with management education. ${ }^{18}$ Patel et al. found that the MD-MBA graduates reported mostly positive attitudes towards their training and that many pursued leadership and primarily nonclinical roles later in their careers. ${ }^{19}$ We could find no comparable studies about the role of DDS/DMDMBA training for the professional development of a dentist. However, our study's finding that significant percentages of students at dental schools without joint DDS/DMD-MBA programs showed interest in such programs should lead to future research in the outcomes of existing programs.

It is obvious that not all dental students will be interested in these dual-degree programs. Under- 
standing which factors might affect such an interest is therefore important. One potential factor could be students' gender because previous research found that the percentages of female applicants to business administration programs tended to be lower than that of males. ${ }^{21,22}$ Those studies found significant correlations between gender and current business educationrelated interests as well as between gender and the consideration of obtaining an MBA in the future. Additional support for the role of gender was found in a study of the percentages of male vs. female students applying to the joint MD-MBA program at Harvard Medical School: over a six-year period, a mean of $76 \%$ of applicants were male and $24 \%$ were female. ${ }^{21}$

A second factor that might positively affect an interest in attending a joint DDS/DMD-MBA program could be an interest in owning a dental practice in the future. Having a stronger background in business administration might be considered an asset for dentists who are more interested in owning a practice. In our study, respondents' interest in owning a dental practice in the future was correlated with a stronger interest in current and future businessrelated education.

This study had several limitations. First, it is possible that students who were more interested in business-related education were more likely to respond to a survey on that topic. Such a bias could affect the outcomes. However, the fact that 273 students of the total 442 at the home school responded (response rate 62\%) shows that the sample may not have been too different from the total population at this dental school. Second, while the study had the power to test hypotheses about relationships of interest, the numbers of students in certain subgroups were too small to make subgroup comparisons. For example, it would have been interesting to compare the responses of students with previous businessrelated work experiences to the responses of those without such experiences. Future research should explore subgroup differences of interest. One of these comparisons should focus on the relationship between respondents' year in dental school and their understanding of the training they received. Third, this study was limited to recruiting students from dental schools that did not already have a DDS/ DMD-MBA program. It would be useful to compare these students' responses to those of students in the 14 schools that have a dual-degree program and perhaps even with responses of graduates from these joint programs. Future research should explore these differences. Finally, it would have been interesting to collect information from the schools concerning the extent of their practice management education. Merely assessing the students' subjective perceptions of the adequacy of their management training and their interest in future training does not allow us to draw conclusions concerning the objective extent of curricular content in this area.

\section{Conclusion}

The findings of this study suggest that the percentages of dental students who are satisfied with their business-related training at their dental school or who agree that their dental school adequately prepares them for the business aspects of dentistry are low. The study also found that the majority of respondents had a current interest in learning more about the functional areas of business and agreed that it is important that dentists learn about businessrelated matters. The majority would strongly consider enrolling in a dual DDS/DMD-MBA program. If time and finances were not a consideration, more than two-thirds of these students would choose to apply to such a joint program. The majority also agreed that their school should offer such an elective program, and half of them agreed that offering dual enrollment for DDS/DMD and business education would have positively affected their decision to apply to their school. Future research should explore how such joint programs could play a positive role in preparing future dentists for changes in dental practice patterns.

\section{Acknowledgments}

We want to thank the academic deans who forwarded the recruitment emails to their students and the dental students who responded to this survey. We could not have done this research without your help.

\section{REFERENCES}

1. Bailit HL. The oral health care delivery system in 2040: executive summary. J Dent Educ 2017;81(9):1124-9.

2. Guay AH, Wall TP, Petersen BC, Lazar VF. Evolving trends in size and structure of group dental practices in the United States. J Dent Educ 2012;76(8):1036-44.

3. Jones JA, Snyder JJ, Gesko DS, Helgeson MJ. Integrated medical-dental delivery systems: models in a changing environment and their implications for dental education. J Dent Educ 2017;81(9 Suppl):eS21-9.

4. Laffer B. Dental service organizations: a comparative review. Laffer Associates, 2012. At: www.heartland.org/ templateassets/documents/publications/20120918 2012. 09.1 9dsos.pdf. Accessed 12 Jan. 2018. 
5. Amadeo K. Economies of scale. At: www.thebalance.com/ economies-of-scale-3305926. Accessed 20 May 2018.

6. Bain CA. Corporate dentistry: a 2020 vision. Dent Update 2000;27(4):163-4.

7. Oral Health Workforce Research Center. Trends in the development of the dental service organization model: implications for the oral health workforce and access to services. School of Public Health, University at Albany, State University of New York. At: www.oralhealthworkforce.org/wp-content/uploads/2017/09/OHWRC_Trends in_Dental_Service_Organization_Model_20 17 .pdf. Accessed $2 \overline{1}$ Feb. $20 \overline{1} 8$.

8. Berg JH, Mouradian WE. Integration of dentistry and medicine and the dentist of the future: changes in dental education. J Calif Dent Assoc 2014;42(10):697-700.

9. Fontana M, Gonzalez-Cabezas C, de Peralta T, Johnsen DC. Dental education required for the changing health care environment. J Dent Educ 2017;81(8 Suppl):eS153-61.

10. Okwuje I, Anderson E, Valachovic RW. Annual ADEA survey of dental school seniors: 2009 graduating class. J Dent Educ 2010;74(9):1024-45.

11. Garrison G, Lucas-Perry E, McAllister DE, et al. Annual ADEA survey of dental school seniors: 2013 graduating class. J Dent Educ 2014;78(8):1214-36.

12. Wanchek T, Cook BJ, Valachovic RW. Annual ADEA survey of dental school seniors: 2016 graduating class. J Dent Educ 2017;81(5):613-30.

13. Dunning DG, Lange BM, Madden RD, Tacha KK. Prerequisites in behavioral science and business: opportunities for dental education. J Dent Educ 2011;75(1):77-81.

14. Willis DO. Using competencies to improve dental practice management education. J Dent Educ 2009;73(10):1144-52.

15. Commission on Dental Accreditation. Accreditation standards for dental education programs. 2016. At: www. ada.org/ /media/CODA/Files/pde.pdf?la=en. Accessed 21 Feb. 2018

16. Henry JB. MD-MBA: a dual degree whose time has come. JAMA 1987;257:1727-8.

17. Flynn D. Dual degree medical programs. At: www.student doctor.net/2010/05/dual-degree-medical-programs/. Accessed 21 Feb. 2018.
18. Larson DB, Chandler M, Forman HP. MD/MBA programs in the United States: evidence of a change in health care leadership. Acad Med 2003;78(3):335-41.

19. Patel MS, Arora V, Patel MS, et al. The role of MD and MBA training in the professional development of a physician: a survey of 30 years of graduates from the Wharton Health Care Management Program. Acad Med 2014;89(9):1282-6.

20. HSDM/HBS MBA/DMD program. Harvard Business School. At: www.hbs.edu/mba/academic-experience/ joint-degree-programs/Pages/harvard-school-of-dentalmedicine.aspx. Accessed 9 Nov. 2018.

21. Krupat E, Dienstag JL, Kester WC, Finkelstein SN. Medical students who pursue a joint MD/MBA degree: who are they and where are they heading? Eval Health Prof 2017;40(2):203-18.

22. Estrada-Worthington R. 2016 application trends survey report. At: www.gmac.com/market-intelligence-andresearch/research-library/admissions-and-applicationtrends/2016-application-trends-survey-report.aspx. Accessed 20 Feb. 2018.

23. DeVellis RF. Scale development. Thousand Oaks, CA: Sage, 1991.

24. DeVellis RF. Scale development: theory and applications. Thousand Oaks, CA: Sage, 2003.

25. Wanchek T, Cook BJ, Anderson EL, Valachovic RW. Annual ADEA survey of dental school seniors: 2014 graduating class. J Dent Educ 2015;79(9):1108-28.

26. Wanchek T, Cook BJ, Anderson EL, Valachovic RW. Annual ADEA survey of dental school seniors: 2015 graduating class. J Dent Educ 2016;80(5):612-29.

27. Barber M, Wiesen R, Arnold S, et al. Perceptions of business skill development by graduates of the University of Michigan Dental School. J Dent Educ 2011;75(4):505-17.

28. Brown LJ. Future organization of oral health services delivery: from 2012 to 2042. J Dent Educ 2017;81(9 Suppl):eS1-10.

29. Weintraub JA. What should oral health professionals know in 2040: executive summary. J Dent Educ 2017;81(8):1024-32. 